\title{
La venganza de Sancho Panza: cartas y sátiras de Juan Manuel de Viniegra, secretario de don José de Gálvez, 1765-1770*
}

\author{
por Salvador Bernabéu Albert
}

\begin{abstract}
Following his imprisonment, the confiscation of his papers, and his expulsion from New Spain, Juan Manuel de Viniegra, who had been a faithful and diligent secretary in the service of Visitor-General José de Gálvez during his expedition to the northwestern provinces of the viceroyalty, found himself in the necessity of reconstructing from memory the major events of the trip. During this ill-starred expedition Gálvez suffered a transitory form of insanity, leading him to commit a number of bizarre actions, which his partisans tried hard to remove from the administrative and historical records and his detractors were equally interested in bringing to light. Gálvez counted among his defenders his own family members, the Marquis de Croix, and the Spanish ministers Campomanes and Floridablanca, while he faced formidable critics in the Secretariat of the Indies headed by the bailiff Julián Valdés. This is how Viniegra found the resources and the strength to construct the memory of his odyssey through different kinds of written works, including historical descriptions and lists of economic expenditures as well as a satirical essay in which he compared Gálvez to Don Quijote. These documents illustrate the limits, tensions, and contradictions of the Enlightenment projects and visions emanating from the court of Charles III.
\end{abstract}

La detención, el secuestro de documentos y la expulsión de la Nueva España de Juan Manuel de Viniegra, diligente secretario del visitador general don José de Gálvez en su expedición al noroeste del virreinato, lo obligó a reconstruir la memoria de lo ocurrido en el viaje. Durante el mismo, el visitador malagueño sufrió una locura transitoria, realizando numerosas acciones disparatadas que sus partidarios quisieron eliminar (los familiares, el virrey Croix, los ministros reformistas encabezados

Este trabajo se enmarca en el proyecto de investigación "Las fronteras y sus ciudades: herencias, experiencias y mestizajes en los márgenes del imperio hispánico (s. XVI-XVIII)" (HUM2007-64126), del Ministerio de Ciencia e Innovación de España. 
por Campomanes y Floridablanca), mientras que los contrarios (con el secretario de Indias, el bailío Julián Valdés, al frente) las anhelaron recuperar. Así fue como Viniegra obtuvo las facilidades y el aliento para construir la memoria de su odisea mediante una serie de escritos de diversa naturaleza: desde la descripción histórica y la lista de gastos económicos al relato satírico donde se comparaba a Gálvez con el Quijote. Estos documentos representan los límites, las tensiones y las contradicciones de los proyectos ilustrados de Carlos III.

\section{INTRODUCCIÓN}

Entre los episodios más curiosos del reformismo borbónico en la Nueva España se encuentra la expedición que emprendió don José de Gálvez, visitador general de todas las cajas, tribunales y ramos de la Real Hacienda en el citado virreinato, a las provincias del noroeste de México. Gálvez, ex-seminarista, abogado y alcalde de Casa y Corte antes de llegar al Nuevo Mundo, se convirtió en el principal agente de lo que el profesor Brading denominó la revolución en el gobierno: ${ }^{1}$ un programa de reformas que buscaba fortalecer las defensas del Imperio español y modernizar su aparato administrativo y judicial para fiscalizar adecuadamente un territorio colonial que debía sostener a la metrópoli con plata, oro y productos primarios. Llegado a la Nueva España el 26 de abril de 1765, Gálvez pronto superó los cometidos que le fueron asignados en las instrucciones ${ }^{2}$ y se convirtió en el

1 David Brading, Mineros y comerciantes en el México Borbónico, 1763-1810 (México, D.F. 1975), pp. 55-132.

2 José de Gálvez y Gallardo, quien nació en 1720 en Macharavialla y murió en 1787 en Aranjuez, realizó un programa de enorme trascendencia en diversos ámbitos de la administración del virreinato, destacando sus reformas de las rentas estatales, buscando siempre el aumento de los ingresos de la Corona. Dos de las innovaciones más importantes estuvieron dirigidas a modernizar el estanco de tabaco y la minería (rebaja del precio del azogue y fundación del Real Colegio de Minería), si bien la presencia de Gálvez se dejó sentir en otros numerosos asuntos, desde el registro del galeón de Manila y la inspección personal de la feria de Jalapa a las reformas de aduanas, salubridad y seguridad de las ciudades, reparto de tierras, fundación de puertos, barrios y poblados, etcétera. Sobre el tema, véase Felipe Castro Gutiérrez, "Del paternalismo autoritario al autoritarismo burocrático. Los éxitos y fracasos de José de Gálvez, 1764-1767": Jaime E. Rodríguez, Mexico in the Age of Democratic Revolutions, 1750-1850 (Boulder/London 1994), pp. 21-55. 
impulsor de numerosos cambios como poblador y promotor de nuevas conquistas, en algunos casos organizadas con la aprobación de Carlos III y en otras sólo con la anuencia del virrey marqués de Croix, su gran colaborador y amigo. Así ocurrió cuando, tras la expulsión de los jesuitas y la campaña punitiva contra varias ciudades en rebeldía que se saldó con un gran número de condenados y ajusticiados - el visitador dejó los trabajos que le habían sido encargados por el monarca en manos de sus dependientes e, investido con todos los poderes del virrey, abandonó la capital rumbo a los territorios noroccidentales del virreinato (Guadalajara, Nayarit, California y Sonora) sin contar con la aprobación explícita del rey.

El Noroeste, tierra de misiones jesuitas, presidios precarios, famélicas minas, guerras continuas con pueblos indígenas y eternos enfrentamientos entre las autoridades laicas y religiosas, se convirtió para Gálvez en el mítico Ofir que solucionaría los apuros económicos del imperio, además de considerar su pacificación y colonización como una ocasión única para entrar en la historia como el segundo conquistador de México: un nuevo Hernán Cortés que sujetaría, definitivamente, estas tierras a la autoridad del rey de España. Pero los resultados fueron adversos, pues aunque se consiguieron algunos logros (la fundación del departamento marítimo de San Blas de Nayarit, el aumento del control real en zonas fronterizas y el diseño de varios proyectos políticos y económicos), ${ }^{3}$ las expectativas creadas por Gálvez no se correspondieron con los numerosos gastos realizados.

El esfuerzo titánico del visitador durante varios meses por tierra y mar, atravesando selvas y desiertos, sin comodidades, con temperaturas extremas y una actividad frenética, lo llevó a las puertas de la muerte a causa de una grave enfermedad. Su regreso a México se aceleró a través de Chihuahua, Zacatecas y Querétaro. Durante la dolencia, Gálvez, víctima de una locura transitoria, protagonizó varios episodios suculentos que fueron presenciados por los habitantes y autoridades de las misiones, reales y presidios en los que se detuvo a

3 Sus ideas sobre el fomento y el gobierno de estas regiones fronterizas fueron recogidas en el "Plan para la erección del gobierno y Comandancia General que comprende la península de California y provincias de Sinaloa, Sonora y Nueva Vizcaya" (1768), cuya principal medida - la comandancia general - fue puesta en marcha cuando el abogado malagueño fue elegido secretario de Indias en 1776. Véase Luis Navarro García, Don José de Gálvez y la Comandancia General de las Provincias Internas del Norte de Nueva España (Sevilla 1964). 
lo largo de seis meses. ${ }^{4}$ Con gran rapidez, los rumores sobre la enfermedad del hombre más poderoso del virreinato se esparcieron por todo el territorio y llegaron a la Ciudad de México, siendo confirmados y ampliados por los informes de los diversos miembros de la comitiva que lo acompañaba y las cartas que remitieron las autoridades locales. Docenas de escritos, respetuosamente pero con toda claridad, informaron al virrey y a los dependientes principales de la visita del lamentable estado de José de Gálvez.

Autorizado por el virrey Croix el regreso del visitador, la salud y la cordura de Gálvez se fueron restableciendo conforme avanzaba hacia la capital mexicana. La lucidez le produjo una gran inquietud por los episodios protagonizados mientras estaba enfermo y, sin calcular las consecuencias, ordenó la detención de los tres secretarios que le acompañaban, Juan Antonio Gómez de Argüello, Miguel José de Azanza y Juan Manuel Viniegra, y la del anciano piloto e ingeniero Antonio Faveau Quesada, que también regresaba en su compañía. Sin juicio y sin una acusación concluyente, los detenidos y sus criados fueron encerrados en el ex-colegio jesuita de Tepozotlán durante ocho meses y posteriormente expulsados del virreinato con el estigma de haber sido apartados de sus puestos oficiales de forma violenta.

Una vez en España, conocemos con precisión las andanzas de Juan Manuel de Viniegra - el rastro de Argüello se diluye y Azanza quedó en Cuba junto a unos parientes, cuyos escritos han servido a los historiadores para reconstruir con detalle las aventuras de Gálvez "mientras corrió soñando por los áridos desiertos de Californias y por las provincias de Sonora y Nueva Vizcaya". Más inadvertida ha pasado la singularidad y especificidad de los textos redactados o recopilados por el secretario, cuyo testimonio de primera mano sobre su detención y los esfuerzos para lograr reincorporarse a la carrera administrativa son un material excepcional para analizar el vínculo que liga los escritos con el poder, entendiendo los mismos como el resultado directo de la autoridad. Viniegra, cuyo trabajo como escribano y secretario consistía en redactar y copiar miles de cartas, reglamentos e informes generados

4 Sobre la locura del visitador véanse Héctor Cuauhtémoc Hernández Silva, "El visitador José de Gálvez en Sonora. La locura de la modernidad, 1769-1771": XVII Simposio de Historia y Antropología de Sonora, tomo 1 (Hermosillo 1991), pp. 217-237; e Ignacio del Río, "Autoritarismo y locura en el noroeste novohispano. Implicaciones políticas del enloquecimiento del visitador general José de Gálvez": Estudios Novohispanos 22 (México, D.F. 2000), pp. 111-138. 
por el visitador, ocultando su yo bajo el peso de la administración indiana, es forzado por las circunstancias a dirigir el discurso y a inaugurar en varios documentos (ego-documentos los bautizó el historiador holandés Jacob Presser en 1958) su propio testimonio sobre la injusticia sufrida y sobre lo que ocurrió realmente durante la expedición.

Nuestro trabajo pretende analizar los testimonios escritos enmarcados en el horizonte social en el que se inscriben y del que forman parte, pues como señaló Jerome J. McGann:

"Los textos son producidos y reproducidos bajo condiciones sociales e institucionales específicas, y por tanto [...] cada texto, incluyendo aquellos que pueden parecer puramente privados, son textos sociales. Esta visión trae consigo un colofón, entendiendo que un 'texto' no es 'una cosa material' sino un evento material o serie de eventos, un punto en el tiempo (o un momento en el espacio) donde se practican ciertos intercambios comunicativos". ${ }^{5}$

A estos escritos de diversa naturaleza, reunidos por Viniegra a lo largo de unos cuatro años, le dedicaré el siguiente análisis, pues si bien se ha editado y utilizado con profusión uno de esos documentos (los Apuntes instructivos), no se ha analizado la colección que lo contiene, dispuesta por el propio Viniegra para que fuese leída por un público general, y que constituye, a mi entender, una atalaya desde la que mirar y acercarnos a la cultura escrita durante los primeros años de las Reformas Borbónicas en América.

\section{LA MEMORIA Y LOS MEMORIALES}

Según Reinhart Koselleck, entre 1750 y 1850 se produjo un cambio en la dinámica de la conciencia histórica de los ciudadanos como resultado del desarrollo político, cultural, socioeconómico y técnico. Apareció una nueva conciencia de que la humanidad podía intervenir en el futuro, decidir su existencia en él, ya que se presentaba lleno de posibilidades y expectativas: "El futuro se convierte en un desafío o en un enigma". ${ }^{6}$ Viniegra, condenado sin juicio y expulsado de la administración real por haber cumplido correctamente con su rey, se convierte

5 Jerome J. McGann, The Textual Condition (Princeton 1991), p. 21, citado por Alison Weber, "Autobiografías por mandato: ¿ego-documentos o textos sociales?": Cultura Escrita \& Sociedad 1 (Alcalá de Henares 2005), pp. 116-119, aquí: p. 117.

6 Reinhart Koselleck, Futuro pasado. Para una semántica de los tiempos históricos (Barcelona 1993), p. 317. 
en el azote del visitador y comienza una lenta batalla para modificar su presente y su futuro.

El resultado textual de esa contienda fue un volumen misceláneo de diversas cartas, memoriales, noticias, apuntes, relación de documentos y listado de cantidades, del cual se conservan dos manuscritos. ${ }^{7}$ Algunas de las partes, desgajadas, circularon con profusión, siempre de forma manuscrita, y de varios documentos se conservan los originales en los archivos españoles y mexicanos. Me interesa indagar por qué se recopiló este gran mosaico documental y si fue una práctica habitual en la época o sólo un hecho aislado. Como señaló Philip Benedict: “[...] comprender el porqué la gente escribió y preservó documentos personales es el punto de partida para extraer de ellos la sangre que nosotros, los vampiros, necesitamos para sobrevivir". ${ }^{8} \mathrm{El}$ inventario del mismo es el siguiente:

“-[1] Introducción

-[2] Carta escrita después de estar en libertad y poco antes de embarcarme en Veracruz para España. Manuel de Viniegra, Miguel José de Azanza y Juan Antonio de Argüello. Veracruz, 19 de diciembre de 1770.

-[3] Respuesta, seguida de posdata [de José de Gálvez]. México, 9 de enero de 1771.

-[4] Respuesta firmada por Juan Manuel de Viniegra, Miguel José de Azanza y Juan Antonio Gómez de Argüello, La Habana, 6 de febrero de 1771.

-[5] Copia del primer memorial presentado por Viniegra en consecuencia de la grata insinuación que para ello mereció del ilustrísimo señor bailío fray don Julián de Arriaga, ministro de Indias. Aranjuez, 23 de mayo de 1771.

-[6] Nota.

-[7] Apunte instructivo de la expedición que el ilustrísimo señor don José de Gálvez, visitador general de Nueva España, hizo a la península de Californias, provincias de Sonora y Nueva Vizcaya, desde que la resolvió y emprendió hasta que volvió a México. Comprende las ocurrencias y hechos más notables, con referencia a papeles y documentos originales que deben existir en la secretaría del virreinato de Nueva España y a sucesos y hechos públicos y notorios en aquellas partes, dispuesto con orden superior por don Juan Manuel de Viniegra, secretario de dicho señor ministro y de la expedición, que siguió y sirvió hasta su vuelta a México. Madrid, 10 de junio de 1770.

-[8] Adicción.

-[9] Advertencias.

7 El más completo se encuentra en el Archivo Histórico Nacional de Madrid (en adelante AHN), sección Estado, legajo 2845. Este manuscrito es el que seguimos para el presente trabajo. Una segunda colección, con el título: Varios papeles escritos después de practicado el viaxe a Californias, Sonora, y Nueva Vizcaia por el visitador general del reino de Mexico, Don José de Gálvez, se custodia en la Biblioteca Bancroft (California, USA) con la referencia BANC MSS $86 / 87 \mathrm{~cm}$.

8 Philip Benedict, "Producción y conservación de las 'tecnologías del yo"”: Cultura Escrita \& Sociedad 1 (Alcalá de Henares 2005), pp. 40-41, aquí: p. 41. 
-[10] Nota de algunas cantidades que tengo noticia han consumido las expediciones proyectadas y practicadas por el visitador general de Nueva España, don José Gálvez, en el puerto de San Blas, península de Californias y provincia de Sonora, exigidas de los sujetos que se expresarán y del real erario. Madrid, 16 de octubre de 1771. -[11] Nota de los papeles que exhibieron judicialmente estando arrestados don Juan Manuel de Viniegra y don Miguel José de Azanza, hecho de orden del virrey marqués de Croix por el ayudante mayor de dragones de España don Juan Velázquez. Los cuales documentos llevaban desde la provincia de Sonora a México para hacer ver a su excelencia sobre los informes y a dirigidos el grado infeliz en que estuvo por su enfermedad el ilustrísimo señor don José de Gálvez.

-[12] Siguen algunos papeles de los innumerables que dictó y escribió el señor visitador estando con los accesos furiosos de su accidente.

-[13] Copia del nombramiento de oficial mayor. Castillo de San Juan de Ulúa, 12 de agosto de 1765.

-[14] Copia del secretario. México, $1^{\circ}$ de abril de 1768.

-[15] Copia de algunos memoriales que he presentado al señor bailío. Aranjuez, 28 de mayo de 1771.

-[16] Otra. El Pardo, 17 de febrero de 1772.

-[17] Otra. Madrid, 16 de julio de 1772. Le acompaña una nota.

-[18] Otra. Madrid, 17 de julio de 1772. Le acompaña una nota.

-[19] Otra. Madrid, 7 de octubre de 1772.

-[20] Otra. Madrid, 26 de enero de 1773.

-[21] Otra. Madrid, 31 de octubre de 1772.

-[22] Otra al visitador general. Madrid, 6 de mayo de 1773.

-[23] Otra al señor bailío. Madrid, 12 de junio de 1773.

-[24] Aviso.

-[25] Conversación que el teniente coronel don Gaspar de Portolá, gobernador que fue de Californias, tuvo con un amigo para instruirle de su viaje hecho desde el presidio de Loreto, en la misma península, hasta los puertos de Monterrey y San Francisco, situados al norte de ella y sobre la costa occidental, promovido y dispuesto por el visitador general don José de Gálvez.

-[26] Especies ridículas y ráfagas notorias que produjo el figurón del visitador general de Nueva España, don José Gálvez, mientras corrió soñando por los áridos desiertos de Californias y por las provincias de Sonora y Nueva Vizcaya. Escríbanse para deducir por ellas su carácter y con la mira de satisfacer plenamente el gusto de un caballero que ha mandado extenderlas. Madrid, 20 de septiembre de 1773.

-[27] Notas. -[28] Conclusión.

-[28] Copia de una certificación dada por don José Gálvez. Madrid, 27 de septiembre de 1774.

-[29] Copia de la carta escrita por Viniegra al excelentísimo señor don Julián de Arriaga. Cádiz, 2 de diciembre de 1774.

-[30] Respuesta de don Santiago Sáenz, apoderado de don Juan Manuel de Viniegra."”

Los documentos están dispuestos siguiendo generalmente un orden cronológico, aunque no siempre se cumple. Comienza con dos cartas, firmadas por los tres secretarios de Gálvez el 19 de diciembre de 1770

9 AHN, Estado, leg. 2845, ff. 1-86v. 
y el 9 de enero de 1771 en Veracruz y La Habana respectivamente, cuando los expulsados comienzan el viaje de regreso a la metrópoli, y termina con una carta de Viniegra desde Cádiz, fechada el 2 de diciembre de 1774, cuando está a punto de abandonar España para ocupar un nuevo destino en la administración indiana: tesorero real de las Cajas de Portobelo, en el reino del Perú, lo que significa la restitución de su honra y sus méritos por parte del monarca. En consecuencia, una primera lectura de este conjunto de escritos nos dibujaría simbólicamente un "viaje al revés" (de México a España hasta la vuelta al Nuevo Mundo), de casi cuatro años de duración, en busca del honor perdido. Pero en el interior de la colección nos encontramos con tres narraciones del viaje de Gálvez al Noroeste, puesto que este fue el escenario donde se produjo la locura del visitador y la supuesta traición de sus secretarios.

En la mente de Viniegra está presente el "carácter viajero" y, así, comienza la compilación de textos confesando al "lector curioso" que desde que llegó a Madrid el 20 de mayo de 1771 había deseado dar por escrito, con fidelidad, una "disertación muy circunstanciada, con el proyecto, sucesos, observaciones, países y viajes de mar que comprendió esta decantada expedición". ${ }^{10}$ Pero mientras tanto, espera que el lector se contente con leer "los que en compendio incluyen esos documentos que con otros me han de servir para abrir las zanjas y concluir el premeditado". ${ }^{11}$

Afortunadamente, las crónicas del viaje a la "península de Californias, provincia de Sonora y Nueva Vizcaya" que se incluyen en la colección (el "Apunte instructivo" del 10 de junio de 1770; la "Conversación" de Gaspar de Portolá, y las "Especies ridículas" del 20 de septiembre de 1773) son documentos excepcionales por la libertad y la ironía con los que están escritos, llenos de informaciones que son difíciles de encontrar en otros diarios de viajes contemporáneos por su honestidad, sus críticas, censuras y observaciones. Así, estas relaciones manuscritas son el contrapunto de las crónicas impresas encargadas por el Gobierno virreinal para dar publicidad a las acciones del

\footnotetext{
${ }^{10}$ Ibidem, f. 1v.

11 Ibidem.
} 
visitador y ocultar las numerosas irregularidades que se produjeron durante la expedición al Noroeste. ${ }^{12}$

Frente al impreso, controlado por el poder virreinal, el manuscrito se muestra más eficaz para satisfacer las pretensiones de los autores, que buscan criticar al Gobierno y mostrar sus errores, como era el caso de Viniegra. Pero éste no está solo. Tras el secretario galveño se encuentra un sector inconformista del Gobierno que va a emplear las relaciones manuscritas para anular y desmentir la letra impresa. Viniegra estaba convencido del poder de los manuscritos en la España de los Borbones, como lo estaban los sublevados contra Esquilache o los que protestaron contra el fracaso naval en Orán, acontecimientos ambos que generaron cientos de sátiras y libelos. Sus dotes de escribano, antes puestas al servicio de los proyectos del visitador, servirán ahora para defenderse y mostrar las preocupaciones propias, por lo que podemos alinear sus escritos dentro de los ego-documentos. Y así, en sus escritos realiza una doble función: a la vez que narra los sucesos de la expedición al Noroeste, inserta varios textos donde confiesa el agotador y penoso peregrinaje tras la Corte (Aranjuez, Madrid, El Pardo) para lograr reestablecer su honor y conseguir un nuevo puesto en América.

Dicho peregrinaje tuvo, obviamente, un precio. El 7 de octubre de 1772, Viniegra comunicaba al secretario de Indias que su situación era de "verdadero pobre vergonzante". Vivía provisionalmente con un hermano, capitán del rey, que no podía mantenerlo, por lo que se alimentaba y vestía de los donativos de varias personas caritativas. Días después - el 31 de octubre - escribía a Julián de Arriaga:

"[...] le ruego encarecidamente me dé pan que comer sea donde fuere, en alguna oficialía real u en otro empleo que vuestra excelencia comprenda poder servir útilmente, pues en la absoluta mendicidad que experimento es imposible, señor, que yo subsista más tiempo". ${ }^{13}$

Un año después la situación se agrava: vivía con trescientos reales de vellón que un bienhechor le prestaba, aunque no sabía hasta cuándo, y

${ }^{12}$ Las obras oficiales editadas de corte apologético por la Imprenta del Superior Gobierno son: Extracto de noticias del Puerto de Monterrey (México 16 de Agosto de 1770); Diario Histórico de los Viages de Mar y Tierra hechos al Norte de la California de Miguel Constanzó (México 1770); y Noticia breve de la expedición militar de Sonora y Sinaloa, su éxito feliz, y ventajoso estado en que por consecuencia de ellas se han puesto ambas provincias (México 1771).

13 AHN, Estado, leg. 2845, f. 61r-61v. 
su anciana madre le ayudaba a la "decencia exterior". Finalmente, el 12 de junio de 1773 anunció al secretario de Indias que, si su situación no se resolviera, tendría que dejar Madrid y refugiarse en Burgos "a servir de carga a su anciana madre". Afortunadamente, este mensaje tuvo una respuesta positiva - aunque no inmediata -, pues se insistió en que Gálvez emitiese un informe y se pidió otro reservado al arzobispo Lorenzana - por aquellas fechas ya en su sede de Toledo tras haber pasado por México - que fueron favorables para la causa de Viniegra. Como ya señalé anteriormente, a finales de 1774 se embarcó en Cádiz rumbo a Portobelo para seguir sirviendo al rey.

LA ESCRITURA Y EL PODER: EL PODER DE LA ESCRITURA

No se pueden entender los escritos de Viniegra sin tener en cuenta la ayuda que recibió de importantes políticos de la Corte cuando regresó de Nueva España el 20 de mayo de 1771. En primer lugar, hay que destacar el interés del secretario de Indias, el bailío fray Julián de Arriaga, por conocer con todo detalle lo ocurrido en la expedición al Noroeste de José de Gálvez. El propio Viniegra confiesa que, tras mandarle un informe resumido de sus penurias, el bailío lo llamó y en tres audiencias, "dentro del gabinete", le pidió que formase un apunte

"[...] con el encargo de ceñir todo lo posible los acontecimientos, pero sin omitir señaladamente el de la enfermedad del señor visitador cuanto contribuyese a la claridad y sustancia de ellas [expediciones] para dar cuenta al rey oportunamente".

Así nació la primera relación extensa de los sucesos y ocurrencias del periplo galveciano que tituló Apunte instructivo de la expedición que el ilustrísimo señor don José de Gálvez, visitador general de Nueva España, hizo a la península de Californias, provincias de Sonora y Nueva Vizcaya, que Viniegra firmó el 10 de junio de $1770 .{ }^{14}$

${ }^{14}$ Además de los ejemplares de Madrid y Bancroft, he localizado copias en el sevillano Archivo General de Indias (México, leg. 1243; y México, leg. 1246) y en la Biblioteca Nacional de Madrid (sig. 4494, pp. 411-537). Al menos ha sido publicado dos veces, en Ángela Cano Sánchez/Neus Escandell Tur/Elena Mampel González, Gaspar de Portolá. Crónicas del descubrimiento de la Alta California, 1769 (Barcelona 1984), pp. 265-281; y en Héctor Cuauhtémoc Hernández Silva, La expedición del visitador José de Gálvez al septentrión novohispano 1768-1770 o la locura de la modernidad (Hermosillo 2000). 
El texto fue escrito en apenas dos semanas sin que Viniegra contase con la ayuda de sus notas y documentos personales, que le fueron arrebatados durante su detención en el camino de regreso a México. Ello explica que al final del mismo se le añadió una adición con asuntos que se le habían olvidado en el relato principal. ${ }^{15}$ En 1773 de nuevo se encargó a Viniegra que escribiese un segundo papel aprovechando la estancia en Madrid de Gaspar de Portolá, quien, por orden de Gálvez, había comandado la expedición terrestre y marítima que redescubrió el puerto de Monterrey y puso los cimientos de la Alta California hispana. Lo interesante de esta nueva relación es que fue solicitada por otro personaje muy interesante, don Pedro de Rada, que ocupó la secretaría del virreinato novohispano hasta que Gálvez lo hizo trasladar a España por su oposición a las reformas del visitador, que en 1773 desempeñaba el puesto de oficial mayor de la secretaría de Indias y a quien Viniegra denomina "mi favorecedor". ${ }^{16}$ No tengo dudas de que tanto Arriaga como Rada eran dos de los principales enemigos de José de Gálvez y que utilizaron a Viniegra como un arma contra el poderoso visitador y sus partidarios en la Corte (Grimaldi, Campomanes, Floridablanca y, más tarde, Muniaín). Nuestro personaje era consciente de ello y, por eso, pidió al bailío que lo acogiese bajo su poderosa protección cuando supo de la llegada de Croix y el visitador Gálvez a la Corte.

15 Arriaga quedó satisfecho, pero le pidió un nuevo ejercicio memorístico que completara la exposición con una relación de los ingresos y gastos realizados durante la expedición, la que Viniegra entregó en fecha muy tardía, el 16 de octubre de 1771, encabezándola como Nota de algunas cantidades que tengo noticia han consumido las expediciones proyectadas y practicadas por el visitador general de Nueva España, don José Gálvez. A esta última le siguió otra relación, que también llamó "nota" por no ser un documento exhaustivo: Nota de los papeles que exhibieron judicialmente, estando arrestados, don Juan Manuel de Viniegra y don Miguel José de Azanza, documento que está firmado a principios de septiembre de 1773.

${ }^{16}$ Efectivamente, Pedro de Rada fue secretario del virreinato de la Nueva España durante la visita de Gálvez, pero sus expresiones de descontento por las reformas y la expulsión de los jesuitas le llevaron de vuelta a España por orden real del 24 de octubre de 1767. Tanto él como los otros separados de sus puestos en la Nueva España estaban convencidos de que su desgracia se debía a los informes enviados a la Corte por José de Gálvez. Por ello, no fue casualidad que Rada también favoreciese a Viniegra y lo mantuviese económicamente durante su estancia en la Corte. Véase Luis Navarro García, "Destrucción de la oposición política en México por Carlos III": Anales de la Universidad Hispalense XXIV (Sevilla 1964), pp. 13-46 
No es descabellado pensar que Viniegra y Arriaga tuvieran algún tipo de relación. El primero había nacido en Burgos, donde seguía viviendo su madre en la década de los setenta, mientras que el bailío, originario de Segovia, estaba muy unido a la ciudad castellana. Su padre, Diego Luis de Arriaga, fue nombrado regidor y alcalde mayor perpetuo de Burgos, ${ }^{17}$ y el propio Julián de Arriaga pasó en la ciudad castellana gran parte de su infancia y juventud hasta que entró en la Orden de San Juan de Jerusalén y se trasladó a la isla de Malta con el fin de hacer los votos y, embarcado en las galeras de la orden, perseguir y capturar a los piratas berberiscos y turcos que encontrase en el camino. ${ }^{18}$ A su regreso a España entró en la Marina, ocupando, tras una fulgurante carrera, la secretaría de Marina e Indias entre el 22 de febrero de 1754, bajo el reinado de Fernando VI, y el 28 de enero de 1776, día en el que murió.

Carlos III mantuvo al viejo Arriaga hasta su deceso, pero no hay que olvidar que su peso político en el gabinete fue secundario. Según el conde de Rosenberg, embajador de la emperatriz María Teresa de Austria ante el monarca hispano, Esquilache y Grimaldi tenían anulado a Arriaga, ${ }^{19}$ circunstancia que ratifica el profesor José AndrésGallego: "Arriaga se fue plegando a lo que le insinuaban, pedían o exigían el uno o el otro y, con esto, Esquilache y Grimaldi pudieron intervenir en el gobierno de Indias con cierta amplitud". ${ }^{20}$

No cabe duda para los estudiosos del gobierno de Carlos III que José de Gálvez era una apuesta de Esquilache, aunque formalmente tenía que consultar con Arriaga y esperar la aprobación o el rechazo de los miembros del Consejo de Indias, por lo general muy conservadores. El

${ }^{17}$ Fabrice Abbad/Didier Ozanam, Les intendants espagnols du XVIIIe siècle (Madrid 1992), pp. 55-56. Su hermano mayor, Cayetano, llegó a ser intendente de Palencia y regidor de Burgos, siguiendo la tradición familiar.

${ }^{18}$ Sobre el bailío, véanse Juan Carlos Maestro Castañeda, "Orígenes y formación marinera de un gran hombre de Estado: Julián de Arriaga, 1700-1749”: Ronald Escobedo/Ana de Zabala/Óscar Álvarez, Euskal Herria y el Nuevo Mundo. La contribución de los vascos a la formación de las Américas (Vitoria-Gasteiz 1996), pp. 285-291; y María Baudot Monroy, "Orígenes familiares y carrera profesional de Julián de Arriaga, Secretario de Estado de Marina e Indias, 1700-1776": Espacio, Tiempo y Forma, serie IV, Historia Moderna 17 (2004), pp. 163-185.

${ }^{19}$ En carta al canciller Kaunitz, fechada el 24 de enero de 1764. Citada en José Andrés-Gallego, El motín de Esquilache, América y Europa (Madrid 2003), p. 297, nota 1137.

${ }^{20}$ Ibidem, p. 298. 
marqués siciliano comunicó a las autoridades americanas en 1765 que los asuntos militares se gestionarían en adelante por medio de la secretaría de Guerra que él detentaba - y no por Indias -, de la misma forma que los asuntos fiscales pasarían a la otra secretaría bajo su mando: Hacienda. En resumen, Esquilache tuvo los hilos en sus manos para capitanear las reformas americanas.

Sin embargo, el motín provocado en la Semana Santa de 1766 terminó con las aspiraciones del ambicioso marqués. La salida de Esquilache del Gobierno dio un respiro a Arriaga, quien recibió aliviado a sus nuevos compañeros: Manuel de Roda a Gracia y Justicia - por fallecimiento del marqués de Campo de Villar - y los navarros Miguel Múzquiz y Gregorio Muniaín a Hacienda y Guerra respectivamente. Sin embargo, Grimaldi siguió gobernando el timón, dando continuidad a la junta de secretarios que ya venía reuniéndose, en donde, junto a los citados, se invitó a varios Grandes de España, como el duque de Alba, el conde de Fuentes y Ricardo Wall. No obstante, en los meses siguientes, el mando político se trasladó al Consejo de Castilla tras ser nombrado el conde de Aranda, capitán general de Valencia, como su presidente. $^{21}$

En este cambio de camarillas, Arrillaga tampoco brilló demasiado, acusado de ser un filojesuita. No se contó con él en las reuniones clandestinas - celebradas en la posada de Aranda en enero de 1767, en las que se analizó la pesquisa secreta para descubrir a los autores de los motines -, ni participó en el consejo reunido en el Real Sitio del Pardo para sancionar el extrañamiento de la Compañía. Muy al contrario, se buscó activamente que no se enterara de nada hasta el momento de la expulsión, algo difícil ya que el operativo de salida debía contar con numerosos barcos para trasportar a los padres españoles hasta Italia.

En este clima antijesuita y con el ascenso de los hombres del Consejo de Castilla, el visitador Gálvez tuvo muchos apoyos, y así cuando se examinaron sus actuaciones en Veracruz, fue defendido nada menos que por los fiscales Campomanes y Floridablanca, con los que coinci-

21 Aranda también fue nombrado por el rey gobernador de Madrid y capitán general de Castilla la Nueva. A su lado, el fiscal Campomanes tendría un papel fundamental en las pesquisas de los motines que concluirían con la expulsión de los jesuitas, declarados - exageradamente - como los culpables de los sucesos. En los años siguientes, Campomanes fue atesorando poder en colaboración con el confesor del rey, Osma, y el secretario Manuel de Roda, hombre cercano al rey en los momentos más difíciles, obligando a Aranda a dejar el poder en 1773 . 
día en su regalismo y antijesuitismo. Si bien, su buena estrella se eclipsó momentáneamente cuando fueron estudiadas varias suspensiones de funcionarios de la aduana de México, entre ellas la del superintendente Francisco Alarcón y Ocaña, que contaba con gran prestigio en la Corte. Revisado el caso en el otoño de 1774, los tres fiscales encargados del caso (uno de ellos Campomanes) se mostraron contrarios a las acciones del visitador, tachándolas de excesivas. En consecuencia, dictaminaron que se les pagara cinco años de salario a los acusados - de 1767 a 1772 - y se les colocara en otros puestos de la Hacienda excepto a dos de ellos. ${ }^{22}$ Es probable que la solución del caso de Viniegra, tantos años paralizado, en los últimos meses de 1774 tuviera relación con este ambiente político en contra de Gálvez, aunque el antiguo visitador malagueño siempre gozó del favor del rey y este episodio adverso fue transitorio, accediendo a la secretaría de Indias meses más tarde.

\section{PUBLICA VOX ET FAMA}

Aunque siempre se escribe para una audiencia (Viniegra se dirige tácitamente al "lector curioso", aunque los primeros lectores de sus memoriales y relaciones fueron el bailío Arriaga, el secretario Pedro de Rada y otros altos cargos de la administración) con un propósito latente (justificar sus informaciones al virrey, persuadir de su inocencia y conmover el real ánimo para obtener un nuevo empleo) y de acuerdo a modelos reconocibles (el género epistolar, los memoriales de servicios, las relaciones de viajes, los libros de cuentas, las sátiras), lo que hay que destacar de esta colección textual es que logra, con piezas diferentes, ilustrar la inocencia y el reestablecimiento del honor del autor, el avance de la verdad frente a la mentira y la venganza del paria contra el poderoso. Sin buscar una renovación formal de las partes, el total surge muy novedoso, con una voluntad de convencer y de dirigirse directamente al entendimiento y a la emoción del lector.

La diversidad de documentos nos puede servir para la reconstrucción del yo escritor o, más concretamente, para constatar las diferentes auto-

${ }^{22}$ Linda K. Salvucci, “Costumbres viejas, 'hombres nuevos': José de Gálvez y la burocracia fiscal novohispana, 1754-1800“: Historia Mexicana 130 (1983), pp. 224 264, aquí: pp. 242-244. 
representaciones elaboradas por Viniegra, que cambia según el tipo de documento elegido. En las primeras cartas enviadas a Gálvez antes de abandonar el Nuevo Mundo y en los memoriales al bailío Arriaga domina la doctrina medieval de la publica vox et fama, según la cual la reputación social determina el crédito que se otorgaba a los escritos y a las acciones. Así, en la primera misiva (Veracruz, 19 de diciembre de 1770), los antiguos secretarios se muestran respetuosos con el visitador, correctos en las expresiones, felicitándole por reponerse de la enfermedad y recordando el tiempo en el que los favorecía como un padre, por lo que le piden que "se sirva vindicar nuestra honra, menoscabada con la rigurosa prisión que hemos sufrido". Pero al recibir la respuesta fría y taimada de Gálvez ("mi corazón sólo es propenso a hacer bien a todos"), los desposeídos, ya desde La Habana, redactan una segunda carta en la que van desgranando las injusticias cometidas contra ellos y acusan a Gálvez de ser el principal responsable de sus males.

Viniegra, Azanza y Argüello construyen su discurso en torno a dos ideas rectoras: la lealtad al rey y la verdad de sus informes. Los tres le confiesan a Gálvez que nunca intentaron anularlo ni magnificaron sus dolencias. A la acusación realizada de que los secretarios fueron los que difundieron la locura por el virreinato, le recuerdan que otros que no fueron encarcelados también firmaron los informes y, finalmente, que la noticia corrió como la pólvora por la Nueva España, pues los actos dementes del malagueño fueron presenciados por varios cientos de personas.

El oficio de secretario, con una larga experiencia en la cultura epistolar, les sirve a los tres dependientes galvecianos para desahogar "en lenguaje respetuoso y sincero" sus sentimientos. Todos son conscientes de lo que supone en sus expedientes respectivos una mancha como la que Gálvez les "regala" con el encierro y la expulsión, y por ello insisten en su inocencia. ${ }^{23}$ No hubo ninguna "conjuración", ni fue una "muchachada". Sólo cumplieron su deber, y su deber les privó de la libertad y de la honra tras un proceso irregular. Lo que desconocen Viniegra y sus compañeros es que la ira del visitador por la revelación de su locura también había caído sobre otros funcionarios, como

23 "En todas partes podremos presentarnos", escriben los tres secretarios, "con la frente serena, llevando dentro de nosotros mismos el testimonio más irrefragable de nuestra conciencia, y esperamos por la misericordia de Dios que no en todas partes se nos cierren las puertas, como en México, para la recompensa de nuestros cuales servicios y para la continuación de nuestro mérito en servicio del rey”. AHN, Estado, leg. 2845, fs. 21v-22r. 
Eusebio Ventura Beleña y Matías de Armona, quienes fueron acusados por Gálvez de divulgar la locura.

Durante los largos años de estancia en la Corte, Juan Manuel de Viniegra volvió a insistir en su inocencia y en la injusticia de la que fue objeto, pero entonces introdujo en su discurso la idea persecución/ protección, pues sospechaba que el regreso del virrey y el visitador a España le fuera negativa, ya que "les es notorio que soy el conducto instrumental por donde arribaron al trono todas las noticias de la expedición y estado infeliz del visitador". En consecuencia, el burgalés temió convertirse en el "blanco de sus tiros y su poder". ${ }^{24}$

\section{LA REVANCHA DEL ESCRIBA}

La escritura medida, serena, humilde y respetuosa de las cartas y memorias se vuelve ácida al relatar los viajes junto al visitador. Como señalé anteriormente, el bailío Arriaga había solicitado expresamente a Viniegra un compendio de la jornada a California y Sonora en la que no faltaran los detalles sobre la enfermedad de Gálvez, y aquél cumplió el encargo, enumerando sus demencias, que bautiza como "accidentes", "estado doloroso", "las locuras", "furiosos accesos", "desgraciado acaecimiento", "calenturas malignas", "melancolía" y "terciarias". Pero además, Viniegra se muestra ácido como en la mejor tradición hispánica: un alumno aventajado de Quevedo, pues como ha escrito Fernando Bouza para el Siglo de Oro - que hago válido para el XVIII -, ser autor en esta época "exigía estar preparado para ofender, tanto si era en provecho ajeno como en interés propio. El autor será apodador, coplero y, a fuer de poco, libelista". ${ }^{25}$ Viniegra se alinea con una vieja tradición satírica que está en el centro de nuestra cultura. Bouza escribe al respecto:

"Las causas abiertas por proferir injurias verbales o por la escritura y difusión de textos infamantes contra terceras personas son tan numerosas que bien podría decirse que la cultura ibérica de los siglos XVI y XVII era una cultura de la violencia verbal y escrita", ${ }^{26}$

${ }^{24}$ Viniegra a Arriaga, El Pardo, 17 de febrero de 1772. AHN, Estado, leg. 2845, fs. $55 \mathrm{v}-57 \mathrm{v}$.

${ }_{25}$ Fernando Bouza, Corre manuscrito. Una historia cultural del Siglo de Oro (Madrid 2001), p. 101.

${ }^{26}$ Ibidem, p. 73. 
En los "Apuntes instructivos", Viniegra realiza un resumen crítico de las actuaciones del visitador en su viaje al Noroeste, abarcando desde la salida de México hasta la vuelta. La narración se va deteniendo en los episodios que ofrecen una visión negativa del malagueño, aunque huya de calificarlo. El autor se presenta como observador atento y fiel, dejando al lector (en primer lugar el secretario Julián de Arriaga) que tome sus propias conclusiones, si bien introduce algunas aclaraciones sobre el ánimo de Gálvez ante la realidad que encuentra en su peregrinaje. Así, si en la península californiana el Ofir que esperaba encontrar se convierte en una árida planicie donde apenas se puede cultivar ni sostener poblaciones, su prepotencia y su orgullo lo llevan a multiplicar bandos, reglamentos e instrucciones ("dictaba leyes, bandos y decretos hasta sobre una mosca que viese volar") para persuadir a México y a la Corte de que sus proyectos se estaban cumpliendo fielmente. Pero será a su llegada a la contracosta (Sonora), cuando la dificultad por derrotar a los indios rebeldes refugiados en el Cerro Prieto y otros levantamientos de los naturales, unida a la falta de caudales para seguir la campaña, "le encogieron el corazón y le consternaron el espíritu" de tal manera que se entregó a una profunda melancolía que, junto a unas terciarias, derivó en un proceso de locura.

Entonces, el ex-secretario por mandato de Arriaga - no hay que olvidarlo - se recrea en los pasajes más curiosos de su demencia, los que describe sin tapujos, consciente de que fueron la causa de su tragedia. El primer episodio de su vesania se produjo en la misión de Ures durante la festividad de San Miguel. En este pobre lugar la "entereza y postura" de don José se transformó en familiaridad con los naturales, comiendo "de aquellos extravagantes guisados que sólo a los indios son sabrosos". Y en el presidio del Pitic reveló a don Matías de Armona "que acababa de traerle unos pliegos san Francisco de Asís" y que terminaría con los indios del Cerro Prieto en sólo tres días "con traer de Guatemala seiscientas monas". A continuación fue a visitar los cuarteles, saludando a los soldados y pidiéndoles que fueran sus amigos y camaradas. También les prometía el dinero que quisieran, por lo que la casa del tesorero se transformó en un "jubileo plenísimo".

Trasladado de nuevo a la misión de Ures, tuvo un segundo acceso que le duró cuarenta y tres días, en los cuales se multiplicaron los actos dementes: 
"Se ponía a las ventanas de aquella misión [y], llamando a cuantos pasaban, les contaba con grandes gritos a unos que él era el generalísimo de aquellas provincias con toda la potestad del rey y del Papa, y a otros dispensaba gracias que salían a mucha distancia de la línea de sus facultades." ${ }^{27}$

Mejorada su salud se dispuso el viaje a México tras recibir la autorización del marqués de Croix. La comitiva partió el 3 de febrero de 1770 de la misión de Ures, pero a las pocas jornadas Gálvez sufrió de nuevo un tercer acceso que obligó a sus dependientes a acampar en la misión de Arispe, donde volvieron a repetirse las acciones más disparatadas hasta el 28 de marzo:

"Llamábase y se tenía por el rey de Prusia, por Carlos XII de Suecia, por Protector de la Casa de Borbón, por Consejero de Estado, por lugarteniente del almirante de España, por inmortal e imposible, por San José, el venerable Palafox y, lo que es más que todo, por el Padre Eterno, con otros infinitos personajes de cuyo carácter cada momento se revestía, queriendo hacer las funciones correspondientes a ellos hasta celebrar el Juicio Final en calidad de Verbo Divino. Nos persuadía a que cinco veces se había muerto y otras tantas resucitado, después de haber visto el cielo empíreo. Intentaba hacer ciudades y trasladar lo material de los pueblos a los desiertos de Nueva Vizcaya. En pocos días inventó y mandaba fabricar una especie de navíos que, por medio de ciertos tornillos, debían servir y transformarse en galeras cuando la necesidad lo pidiera, aún en alta mar. Proyectaba un canal desde la laguna de Chalco, a dos leguas de México, hasta el puerto de Guaimas, en Sonora, capaz de navegar en ella navíos de ochenta cañones. Distribuía capelas, mitras, collares del toisón, hábitos de las órdenes militares, cruces de San Luis y tenía imperios que regalar". ${ }^{28}$

No había fuerza o remedio con el que sosegar al visitador, que se entretenía en quebrar cerrojos de hierros, romper sillas y ventanas y desnudarse, apareciendo de tal guisa en las ventanas

"[...] para predicar a los indios y asegurarles que él era el emperador Moctezuma y que los dogmas de la religión cristiana estaban reducidos a estos dos artículos: creer en Nuestra Señora de Guadalupe y en Moctezuma". ${ }^{29}$

En medio de su locura escribió muchos papeles y, entre ellos, el siguiente: "José de Gálvez, loco para el mundo, infeliz para él. Rueguen a Dios que sea feliz en el otro". ${ }^{30}$

\footnotetext{
27 AHN, Estado, leg. 2845, f. 40r.

28 Ibidem, fs. $41 \mathrm{v}-42 \mathrm{r}$

${ }^{29}$ Ibidem, f. 42r.

${ }^{30}$ Ibidem.
} 
Estos episodios acaecieron a lo largo del camino hasta el presidio de Fronteras, llegándose incluso a elegir una tumba para el visitador en la misión de Cuquiárachi, pero el enfermo fue reponiéndose a partir del 28 de febrero y entró muy mejorado en Chihuahua el 30 de marzo y casi repuesto en la Ciudad de México. Durante el camino, como ya señalé, se produjo la detención de sus secretarios. Al final de la relación, Viniegra confesó: "que he conseguido hacer este apunte liso y llano, y que lejos de la ofensa y exageración, no se encontrará sino simple y sencilla la verdad". Sin duda, aunque no lo exprese abiertamente, la simple relación de los acontecimientos muestra la injusticia padecida, y el solo listado de actos dementes de Gálvez anulaba los informes positivos que tanto el virrey como el visitador enviaron a la Corte sobre los avances y beneficios de la presencia del visitador en el Noroeste.

El tono contenido de los Apuntes instructivos cambia por completo con la relación, también de Viniegra, titulada Especies ridículas y ráfagas notorias que produjo el figurón del visitador general de Nueva España, don José Gálvez, mientras corrió soñando por los áridos desiertos de Californias y por las provincias de Sonora y Nueva Vizcaya. Escríbense para deducir por ellas su carácter y con la mira de satisfacer plenamente el gusto de un caballero que ha mandado extenderlas. Este segundo texto de Viniegra sobre la expedición al Noroeste, firmado el 20 de septiembre de 1773, se centra en los acontecimientos de la California, aunque también recoja otros episodios que se le olvidaron en la primera relación de sus viajes.

Las palabras que Viniegra dedica a Gálvez son muy ingeniosas: "figurón", "fantasma de carne y hueso", "elefante zaramullo", "personaje de farsa", "energúmeno", "fanfarrón andaluz", "nuestro hombrón", "golilla", "frívolo y temerario", "frenético", "estafermo" y "el maldito". No le van a la zaga los defectos: prepotencia ("Dichosa es Nueva España con mi venida"), despotismo, crueldad ("seré el Atila vengador"), taimado ("corazón ferino de Gálvez"), iluminado ("su viaje había sido inspirado por celeste impulso"), hipócrita, impío, supersticioso ("que fue firmar sus negras sentencias con una pluma de la venerable madre María Jesús de Agreda que le regalaron en México"), embustero, alucinado y estéril ("los famosos bandos [...] sólo serían leídos de los coyotes, leopardos y de los indios, que son tan buenos lectores del idioma español como aquéllos"). 
La principal acusación que Viniegra hizo a Gálvez es que transformó la realidad de las regiones del Noroeste, convirtiéndolas en lugares de grandes potencialidades para no desdecirse de las promesas que había repetido incesantemente a Carlos III. Las alucinaciones de José de Gálvez ante la pobreza y la aridez que contemplaba a su alrededor lo convirtieron en un candidato ideal para compararlo con el personaje literario más importante de la literatura española: Don Quijote. La quijotización del visitador era una apuesta segura para desacreditarlo, mandar un mensaje efectista a los lectores y para anular toda su obra. Viniegra dibuja a Gálvez como el "Real y verdadero don Quijote" y a California como su "Ínsula Barataria". Una vez desembarcado, la fantasía se desbocó, transformando como por encantamiento las chozas en casas, las rancherías en ciudades, los pobres yacimientos en ricas minas capaces de sostener toda la California, los esteros en grandes factorías de pescado y los desiertos de cactus, cirios y chollas en un campo de grana. A su salida, dejó una California más pobre y más frágil que a su llegada.

\section{EPílogo}

Juan Manuel de Viniegra, el fiel "Sancho", se venga de su señor y, centrándose no en sus episodios demenciales, sino en su falta de realismo y su constante visión alucinada de los hombres y los paisajes que recorría, se convirtió en lo contrario de lo que se pretendía: en lugar de fomentar las arcas del rey, las vació en cuatro millones y medio de pesos.

Queda por resolver una última cuestión: ¿fue la colección documental de Viniegra un hecho aislado? Anteriormente cité a Eusebio Ventura Beleña como otro de los acusados por Gálvez de propalar la enfermedad que padecía. Ahora me interesa recordarlo de nuevo porque Beleña, contemporáneamente a Viniegra, también coleccionó un gran número de documentos que tituló Manifiesto de la conducta observada por don Eusebio Bentura Veleña en las comisiones a su cargo en esta Nueva España los señores excelentísimos virrey marqués de Croix e ilustrísimo visitador general don Joseph de Gálvez. ${ }^{31}$

${ }^{31}$ Ignacio Almada Bay et al. (eds.), Manifiesto de Eusebio Bentura Beleña (Zamora, Michoacán 2006). 
Una rápida lectura de los mismos (cartas propias y de otros, informes, comentarios, etcétera) puede darnos la sensación de estar ante una maraña difícil de clasificar, pero el estudio detenido de los textos demuestra que el autor no dejó nada al azar, sino que siguió un plan premeditado para defenderse de una grave acusación que le hizo el virrey Croix. ${ }^{32}$ En su defensa, Beleña recopiló esta nueva colección documental - con muchos nombres y episodios que nos recuerdan a Viniegra - para reestablecer su honor, insertando con sus palabras varios textos oficiales y particulares que demostraban su inocencia. En consecuencia, Viniegra escogió para su defensa un modelo empleado por sus contemporáneos, si bien los textos satíricos sobre la figura del gran José de Gálvez lo convierten en un personaje singular en el estudio del reformismo temprano de América y España.

32 El motivo parece haber sido una roca de oro que Beleña envió directamente a la Corte en lugar de entregarla al virrey para que éste la pusiera en el correo. El marqués de Croix inició una campaña muy negativa en su contra para desacreditarlo ante el rey y sus secretarios. 
Brought to you by | CSIC - Unidad Coordinacion Bibliotecas

Authenticated

Download Date | 11/15/19 5:27 PM 